Red-winged Blackbird (c), Western Meadowlark (u), Yellow-headed Blackbird ( $r$ ), Rusty Blackbird (c), Brewer's Blackbird (u), Common Grackle (c), Brown-headed Cowbird (c), Northern Oriole (c), Purple Finch (?), Pine Siskin (?), American Goldfinch (c), House Sparrow $(u)$
*Upon receiving my report on the sighting of the American Tree Sparrow, which occurred in late June, Maurice G. Street expressed some doubt about it. I felt obliged to mention it, however, because I saw the individual bird for several minutes in excellent light.

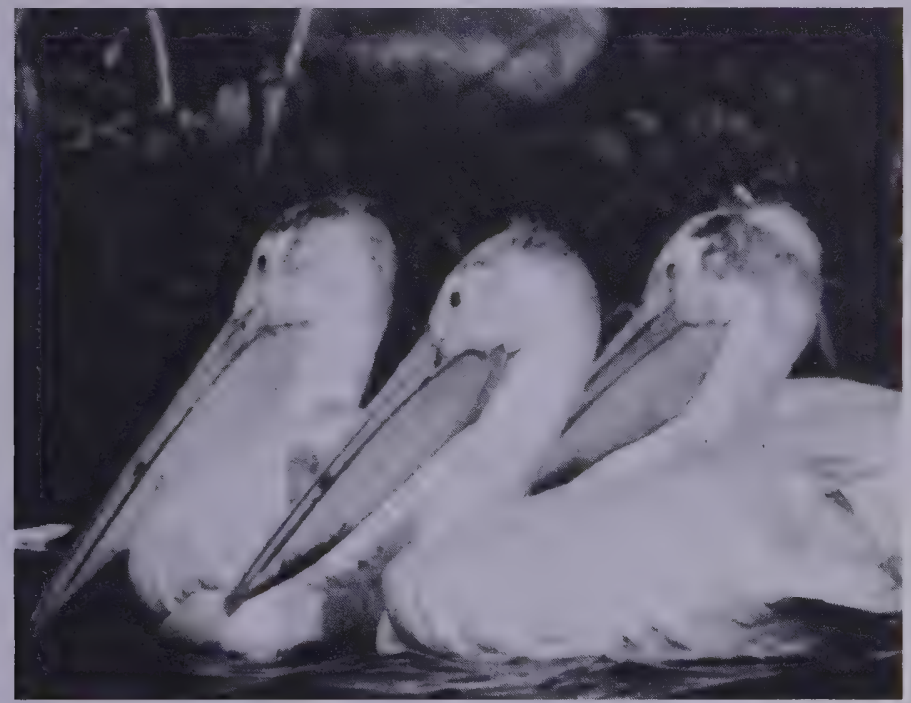

\title{
ERRATIC FLIGHT OF A DOWNY WOODPECKER
}

FRANK H. BRAZIER, 2657 Cameron Street, Regina, Saskatchewan. S4T 2W5

On 19 March 1989 at 10:00 a.m., under a heavily overcast sky, I stepped onto the parking lot in the southwestern angle of the Legislative Building in Regina. I heard the call of a Downy Woodpecker coming from a grove of trees immediately south of the parking lot. I was crossing the lot scanning the grove when a small bird shot out of the group of trees and gave a display of aerobatics I have never seen equalled.
The bird flew at such a rate that it literally disappeared and only the white in the plumage enabled me to follow it at all. It shot upwards, perhaps 30 feet, "jinked" and sped downwards at an acute angle into a shrub; then, without pause, it shot upwards to about the same height, snapped into a reverse and dove at high speed into the shrubbery at the east side of the lot. Then, again without pause, it shot out and into the shrubbery 
on the north side of the lot, where I lost sight of it. As I neared the place, it reappeared, zoomed up, "jinked" again and sped over to the grove of trees on the west side. It came to rest on a tree where I could see that it was a female Downy Woodpecker. It then went about its business calmly in the normal way.

I estimated that the parking lot was 90 $x 180 \mathrm{ft}$., the long sides east and west. The entire episode could not have taken more than 90 seconds.

I have never before seen such amazing manoeuvrability by an ordinary bird. It reminded me of the flight of feeding swifts or bats. The speed was unbelievable and the turning angles at the tops of the upward zooms were incredibly sharp.

After the exhibition I then heard another Downy call from the grove to the south and going there saw a male Downy prospecting a tree. Behind it and higher up in another tree close by was a Hairy Woodpecker. The male Downy then flew over to the female's tree, and the Hairy flew into the same grove but further to the west and settled higher in another tree.

I was puzzled by the extraordinary demonstration put on by the female Downy. I remembered that last winter Elmer Fox and I had witnessed a performance by a Downy Woodpecker seemingly against a Hairy. Both birds were on an old dead tree, the Downy very agitated and keeping up a continuous harsh scolding chatter while flying at the larger bird. The Hairy appeared unconcerned and kept on prospecting on the old tree. We thought then that the Downy recognized in the Hairy a threat to its potential food supply and was protesting accordingly. It was reminiscent of the reaction of a Townsend's Solitaire towards a flock of Bohemian Waxwings which were pillaging its winter supply of Siberian crabapples which I have described (BRAZIER, F.H. 1961. Gray Gladiátor. Blue Jay, 19:119).
The demonstration on 19 March seemed to have no purpose. When I first saw the female Downy she had left the immediate vicinity of the Hairy and gave her breath-taking performance about 100 feet from where the Hairy was found.

I sent copies of my description of the Downy's strange behaviour to Dr. Stuart Houston, Saskatoon, and Dr. Robert W. Nero, Winnipeg. Dr. Houston recommended sending a copy to "...one of the world's leading behaviour experts, probably No.1 for woodpeckers," Dr. Lawrence Kilham, of Lyme, New Hampshire, which I did.

Dr. Nero suggested that what I saw was the end of a stressful situation affecting my Downy. That part of the Legislative Building grounds had been regularly patrolled all winter by Merlins and possibly my Downy "froze" for a period to escape the watchful eye of the falcon. When the predator flew away, the tension was released and I may have seen the result - erratic flight.

Dr. Kilham advised me that he had written about "Erratic Flights" in an earlier book: Life History Studies of Woodpeckers of Eastern North America (Publication No. 20, Nuttall Ornithological Club). I quote most of his informative and interesting letter below:

As described on p. 210 'A second form of play is erratic flight in which woodpeckers suddenly loop in, out, and around trees. This might be regarded as being merely a form of exercise, except that it occurs most frequently at the same time as dodging (i.e., dodging around tree trunks) and may even follow it directly. A Hairy on January 30 dodged before a chickadee, then flew off in erratic flight. This type of flight is a form of dodging on the wing, as if the woodpecker was being pursued by a hawk. I have noted it in the field for Hairies, Downies, as well as for sapsuckers, flickers, Red-cockadeds, Pileateds and Red-bellieds.

Morse (1975, Ibis, 117:379-382) gives a closer description ... in his account of 'erratic flight' of European Goldcrests and Treecreepers. Although most of the flights 
he witnessed were without provocation that he could discover, two, one for each species, were when pursued by a Sparrowhawk.

Thus, although frequently performed as play and a way of exercising, erratic flights can be used as a means of escaping pursuit by a predator. I describe erratic flight in a yearling American Crow in my recent book, THE AMERICAN CROW AND THE COMMON RAVEN (1989, Texas A\&M University Press), p.151.

The erratic flight I witnessed could be that of a highly-strung individual's reaction to a stressful situation as suggested by Dr. Nero; my Downy may have been more exposed to attack than the other two woodpeckers (if a Merlin was present) so they did not perform as she did. Other causes might be those mentioned by Dr. Kilham, i.e., play or exercise.

I am most grateful for the consideration given to my inquiries by by Drs. Houston, Kilham and Nero.

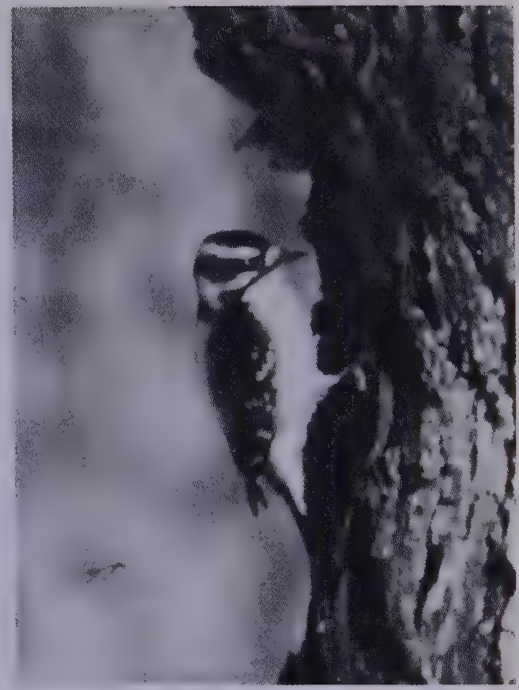

Downy Woodpecker Juhachi Asai

\section{HOODED MERGANSER IN EAST- CENTRAL SASKATCHEWAN}

\section{DONALD F. HOOPER, Box 40, Somme, Saskatchewan. SOE 1 N0}

The Hooded Merganser has been considered a rare species in east-central Saskatchewan. Maurice Street reported one bird for 1948 and one for 1953 in the Nipawin area. ${ }^{3}$ Wayne Harris saw six birds on McBride Lake 18 September 1976 (pers. comm.). Ronald Hooper and I have only four sight records with a total of about 11 individuals seen in the Somme area between 1951 and May 1987. That is why we were surprised to find the species fairly common at Greenwater and Marean lakes in Greenwater Provincial Park while we were doing a survey of waterfowl departure dates during the fall migrations of 1987 and 1988. 